\title{
LEXICON
}

\section{SEMANTIC STUDY: ANALYSIS OF REFERENCES FOR ANIMAL AS OBJECT IN ANIMAL RELATED ARTICLES FROM INTERNET}

\author{
Kartikasari Dwi Rokhmah
}

\begin{abstract}
Intisari
Menganalisa referen pada objek tertentu merupakan studi yang tepat dalam pembahasan text. Skripsi ini menganalisis referen pada hewan dalam artikel-artikel internet. Sumber data adalah dua puluh artikel dengan topik hewan. Sumber data diambil dari news.nationalgeographic.com dan animal.discovery.com. Metode yang digunakan adalah studi pustaka untuk mengumpulkan hasil secara kualitatif. Analisis terfokus pada penggunaan referen dan faktor-faktor yang mempengaruhi penggunaan referen. Hasilnya menunjukkan bahwa referen she (n: 119; 40.8\%) lebih dominan. Hal ini disebabkan oleh gender dan bentuk tunggal. Sebagai tambahan, frekuensi dari referen he (n: 70; 23.9\%), it (n: 41;14.1\%) dan they (n: $62 ; 21.2 \%$ ) dipengaruhi oleh gender, bentuk tunggal, bentuk jamak, asosiasi dan sikap penulis. Namun faktor asosiasi dan sikap penulis tidak konklusif untuk studi ini.
\end{abstract}

Kata Kunci: Kohesi, Referen, Motif-motif, Semantik, Text

\begin{abstract}
Analyzing the reference for particular object is appropriate in the study of text. This paper discusses the reference for animal in internet articles. The data sources are twenty articles with animal topics. They are taken from news.nationalgeographic.com and animal.discovery.com. The method is library research to collect qualitative findings. The analysis is on the use of reference and the factors that influence the use of reference. The findings show that the dominant reference she (n: 119; 40.8\%) is influenced by the gender and singularity. In addition, the frequency of references he (n: 70;23.9\%), it (n: 41; 14.1\%) and they (n: $62 ; 21.2 \%$ ) are influenced by gender, singularity, plurality, association and writer's attitude. However association and writer's attitude factor is not conclusive for this study.
\end{abstract}

Keywords: Cohesion, Reference, Motifs, Semantics, Text

Kartikasari Dwi Rokhmah

Kartikasaridr@gmail.com 


\section{INTRODUCTION}

Reference is a type of meaning binding in English text in which it is categorized as grammatical cohesion (Halliday, Hasan 1976: 43). Generally, the writing of English text uses reference, at least the personal reference. It means that to create cohesion in English text, reference becomes the most commonly used. Therefore analyzing the reference for particular object is appropriate in this study.

Reference can connect a sentence with the previous one through the pronoun. The examples are:

[1] Wash and core six cooking apples.

[2] Put them into a fireproof dish.

(Halliday, Hasan, 1976: 2)

The sentences above show that the pronoun them in sentence [2] can connect the previous sentence [1]. It is done by referring to the noun phrase written in italic. This binding in text is called anaphora (Halliday, Hasan 1976: 14-17). This type of text binding can produce unity in the whole text by using reference.

Unity in cohesion (Georgakopoulou, Goutsos, 1997:14), is an obligatory element in English or other languages text. It can complete the texture of a text. So the meaning is accepted and understood by the reader. This element helps to synchronize the reader's interpretation to the message from the writer.

As mentioned before, pronoun is the common form found in text. The pronoun is $I$, You, We, They, He, She and It. The function is to repeat or substitute a noun or noun phrase. The function of pronoun as reference in English text will be activated automatically.

Reference in English text is generally used for pointing backward. It is called anaphora. And it is identified as endophoric reference (Halliday, Hasan, 1976: 33-7). Hence, anaphoric text is used to connect the meaning of English text as a whole.

In the use of reference, every noun such as persons, things also animals becomes the referent object. Halliday and Hasan (1976: 47) state that the reference to point backward to an object like animal is provided in form of human (he/she) or thing (it). Thus analyzing the references for animal is interesting. As the plural reference, they becomes the other choice to refer to animal. Some argue that they is less definite (Bolinger, 1980). However it will complete the knowledge of reference in relation with the references for animal in English text. Therefore it can be appropriate study to identify the use of reference to refer to animal.

The use of certain reference in an English text must be influenced by several considerations which are based on gender, singular and plural form (Palmer, 1916: 124). It is necessary to reveal the factors in the use of reference in English text that contains animal topics. In understanding the reference; to which it refers to, it is important to understand the meaning. Related with the meaning, Semantics, a study of meaning in text (Lyons, 1977:5), is better to be understood as well. Semantics is focused with the meaning of written text. This study concerns with the meaning of morphemes, words, phrases and sentences (Fromkin, Rodman, and Hyams, 2003: 173; Lyons, 1977:5). In the other side, the writer has important role to decide the use of reference for animal. The writer may influence the reference used. Hence, the motifs of reference used will be investigated.

English articles with animal topic are an appropriate object for the analysis of this study. The articles from internet sites are the sources because they have exclusive topic of animal. The articles are taken from news.nationalgeographics.com and animal.discovery.com. Both sites are 
the leading addresses that provide the information about fauna in the world.

Identifying the use of endophoric reference as cohesive ties is appropriate in the text study. The discussion focuses on the reference used to refer animal. It will talk about cohesion as endophoric sense. Halliday Hasan (1976: 47) stated that "Animals are treated sometimes as persons and sometimes as things" so it will investigate $\mathrm{He}$, Him, His, She, Her, Her, It, It, Its also They, Them, and Their for the additional knowledge. In addition, it will investigate the dominant reference used in the articles taken from internet (news.nationalgeographics.com and animal.discovery.com). By finding the dominant reference to animal, it will represent the general reference used for animal in data sources.

By analyzing the finding, the factors of the reference used he, she, it and they will be explained within Palmer's assumption (1916). These factors influence each reference used. It exposes the semantics study. In the other side the writer attitude becomes another motif. Moreover it can give better understanding in relation with the finding.

The data sources are ten articles from news.nationalgeographics.com and ten articles from animal.discovery.com. The articles chosen contains the reference he,she,it and they. Each article will be coded. Moreover, the data are the reference found in animal articles.

\begin{tabular}{|l|l|l|}
\hline \multicolumn{1}{|c|}{ Code } & \multicolumn{1}{c|}{ Titled } & \multicolumn{1}{c|}{ Author } \\
\hline $\mathrm{Ng} .1$ & 5 Amazing Stories of Devoted Dogs & Rebecca Ascher Walsh \\
\hline $\mathrm{Ng} .2$ & Gorilla Rescue & Scott Elder \\
\hline $\mathrm{Ng} .3$ & Giant Panda Habitat & David M.Rubeinstein \\
\hline $\mathrm{Ng} .4$ & Venus the Two-Faced Cat mystery & Katia Andreassi \\
\hline $\mathrm{Ng} \mathrm{.5}$ & Meet Migaloo,World's First "Archaeology Dog" & Amanda Fiegl \\
\hline $\mathrm{Ng} \mathrm{.6}$ & Amazing Bats of Bracken Cave & National geographic \\
\hline $\mathrm{Ng} \mathrm{.7}$ & Tiny Frogs Ring in Spring & Lyssa White \\
\hline $\mathrm{Ng} \mathrm{.8}$ & Hot Dogs: Doggone Good Time at the Westminster & Jennifer Kirkpatrick \\
\hline $\mathrm{Ng} \mathrm{.9}$ & Emperor Penguins & Catherine D. Hughes \\
\hline $\mathrm{Ng} \mathrm{.10}$ & Can animal be nice? & National geographic \\
\hline $\mathrm{Ad} .1$ & Top 10 Internet Cats of All Time & Animal Planet \\
\hline
\end{tabular}

To collect the data, it is needed personal computer to access the internet network. Internet addresses chosen are national.geographic.com and animal.discovery.com. Both sites contain articles with animal topics. The articles use endophoric reference (he,she, it,they). Twenty articles with their information are moved to word file (*.doc). Finally each article will have a code for the analysis.

This study is based on library research to provide qualitative findings. The analysis use endophoric reference theory by Halliday and Hasan (1976). First the analysis will reveal the use of reference he, she, it and they. In essence, the reference occurrences are classified based on the anaphoric text. It contains the pronoun He, Him, His, She, Her, Her It, It, Its and They, Them, Their. To complete the result, the statistics of anaphoric text (characteristic of cohesive ties) is also provided. Furthermore it will deal with several factors in relation with Palmer theory (1916).

From two sites, there are twenty articles with the coding information available in the table below. The articles are about animal topics. They used the reference $\mathrm{He}$, Him, His, She, Her, Her It, It, Its and They, Them, Their to refer to animal. The articles are taken randomly in around October to November 2013.

1. Table of Article Code 


\begin{tabular}{|l|l|l|}
\hline Ad .2 & Top 10 Famous Racehorses & Animal Planet \\
\hline Ad .3 & Avocet & Animal Planet \\
\hline Ad .4 & Starfish & Animal Planet \\
\hline Ad .5 & Curlew & Animal Planet \\
\hline Ad .6 & Do animals have emotions? & Jessika Toothman \\
\hline Ad .7 & How do animals communicate? & Jessika Toothman \\
\hline Ad .8 & Dragon of Komodo & Animal Planet \\
\hline Ad .9 & Can piranhas really strip a cow to the bone in under a & Julia Layton \\
\hline Ad. 10 & Swan & Animal Planet \\
\hline
\end{tabular}

$\mathrm{Ng}$ : National geographic

Ad: Animal discovery

This study used different data with a research conducted by Serratrice (2007). $\mathrm{He}$ analyzed anaphoric reference but also the cataphoric reference. The context of this study is language-specific strategies in anaphora resolution. It is classified in bilingual and monolingual acquisitions. The data are taken from three groups. The first group is bilingual eight years old children (English-Italian). The second is a group of English monolingual eight years old children. And the third is a group of Italian monolingual adults. The result shows there is no significant distinction among the groups for interpreting anaphoric and cataphoric pronoun. However the bilingual children often accepted reference with a subject than the monolinguals and adults.

Bachmann in 2011 investigates third person direct object of anaphoric reference. The data sources are Evening news programmes in Brazilian TV. He compares the result with the previous research by Bagno(2005), Duarte(1989), Schwenter and Silva(2003). The finding is extremely low in anaphoric pronouns. Hence, the lexical NPs and the passive can develop the anaphoric reference. The researcher concerns on the passive. It is used to establish the anaphoric reference. In the following conclusion, the researcher believes that it affects the quality of reporting. Bachman conducted research in
Pragmatics study that clearly different with this study.

It concerns on endophoric reference. The ties of endophoric reference are the personal reference. Personal reference discusses the use of pronoun to directly refer to possessed noun. This study will be focus on He, Him, She, Her, It, and It as singular pronoun. And it concerns with the other pronoun regards them, such as the possessive His, Her and Its. It also covers plural pronoun such as They, Them and Their. So it can complete the knowledge of reference study. By investigating the use of reference, the dominant reference is found. The anaphoric text is the focus. Moreover, semantics study is important to reveal several factors that influence the reference frequencies. Hence, this study uses Halliday Hasan and Palmer theories to get the finding.

\section{Results and Analysis \\ 2. 1 The Use of Reference}

According to the table below, there are 292 references frequencies that are shown in the twenty articles. There are 423 sentences that are found within anaphoric text. The reference he has 70 (23.9\%) occurrences. Reference she is the dominant. It shows 119 (40.8\%) frequencies. The reference $i t$ is occurred in $41(14.1 \%)$ frequencies. And the plural reference, they has $62(21.2 \%)$ frequencies. The specific explanation of each category will be discussed in the following analysis. 2. Table of References Frequency. 


\begin{tabular}{|c|c|c|c|}
\hline \multirow{2}{*}{ References } & \multirow{2}{*}{$\begin{array}{c}\text { Total } \\
\text { Sentences }\end{array}$} & \multicolumn{2}{|c|}{ Total } \\
\cline { 3 - 4 } & 106 & 70 & 23,9 \\
\hline He, Him, His & 146 & 119 & 40,8 \\
\hline She, Her, Her & 68 & 41 & 14,1 \\
\hline It, It, Its & 103 & 62 & 21,2 \\
\hline They, Them, Their & $\mathbf{4 2 3}$ & $\mathbf{2 9 2}$ & $\mathbf{1 0 0}$ \\
\hline Total & & &
\end{tabular}

The 423 sentences contain 292 references. It is included the presupposed nouns. The presupposed nouns that are used to refer to 292 references are 187 . Even though the presupposed nouns are less than the reference occurrences but they can represent the references in 105 frequencies more. The reason is one presupposed noun can represent to several references. For example the use of reference she (Ng.3) in the excerpt below:

(16)Since ... the cub has grown and passed several developmental...

(17) She weighs five pounds... at $\underline{\text { her }}$ veterinary exam September 26.

(18) She also has partially opened her eyes. (19)Keepers noticed that her right eye had started to open October 4.

Sentences number (16) to (19) show that a presupposed noun in bold underlined (16) can refer to the references in the next three sentences. Hence, a presupposed noun can represent more than one reference in sentences.

Reference is identified by the use of pronoun. It is analyzed based on the class, function and semantic category. Based on the class, head is occurred in 113 (62.4\%) frequencies. And reference used shows $68 \quad(37.6 \%)$ occurrences as determiner. The head is occurred within $113(62.4 \%)$ frequencies. And the modifier has $66(37.6 \%)$ occurrences. According to semantic category, the existential is happened in $113(62.4 \%)$ references. The possessive shows $68(37.6 \%)$ frequencies.
The similarity of frequencies among class, function and semantics category is influenced by the same identification. For example in sentence taken from $\mathrm{Ng} .1$ :

(50) This is the work he was born

to do.

The use of the reference $h e$ in the sentence (50) above represent the same class, function and semantic category. According to the class, he is included into head. Based on function, it is categorized as head. And in semantic category, it is classified as existential. Hence, there is linear classification of the class, function and semantic category.

Another example is seen in the reference her (Ng.2):

(5)Then they took her across the...

In the sentence above, the classification of her according to class is determiner. Based on functions, it is categorized as modifier. And in semantic category, it is included into possessive. Hence, the linear classification is also happened in determiner, modifier and possessive.

The analysis of anaphoric text is discussed in each reference type. Analyzing the reference in anaphoric text conveys the characteristic of cohesive ties. There are mediated and remote (Halliday, Hasan 1976: 339). In addition, reference as one of cohesive ties applies these distances in text binding. The mediated is occurred when the reference placed exactly after the sentence that contains the noun. While the not immediate or remote is happened if the reference is used after one or more than one sentences from the presupposed noun. According to the data, the mediated is illustrated in $105(56.2 \%)$ frequencies. The remote has 82 (43.8\%) occurrences. So there are 184 distances of cohesion found in the 423 sentences.

Total of the characteristic is occurred less than the related sentences. The characteristic concerns about the relation between two sentences. It is focused with the sentence that contains 
presupposed noun and the sentence that used the reference, for example:

(18)In 2006, Barbaro entered the

Kentucky Derby undefeated, ...

(19) Prior to this win, he had also

nabbed...

(20)His impressive record had many

believing he ... three bones in his right

hind leg, bringing his racing career ...

The sentences above are taken from Ad.2.

It represents the mediated distance of cohesion as seen in sentences (18) and (19). The presupposed noun Barbaro is written in sentence (18). Thus is exactly before the sentence (19) that contains the reference he. Sentences (18) and (20) show the remote. The binding is happened after sentence (19).

The example of anaphoric text that used $h e$ as the reference is found in 16 frequencies in Ad.2, for example:

(7)The 1980s were all about John

Henry, voted the racehorse of the ...

(8) $\underline{\mathrm{He}}$ was named after the "steel-

driver" folk hero as a result of the

equine's...

Based on sentence (7) above, the bold underlined John Henry is the presupposed noun. It is followed by the italic underlined reference he in the next sentence. So there is anaphoric binding in the two sentences above. He in (8) functions as head and has position as subject that do some act.

In $\mathrm{Ng.5}$ there are data of she on anaphoric text, as the following excerpt:

(27)What we saw was that the dog was

able to find a buried bone ....

(28)We would even just take ..., ...-

and she could still find the smell.

The reference she in the sentence (28) is pointing back to possessed noun in sentence (27). The element that is possessed is the dog. In essence, there is anaphoric binding in these sentences.

The anaphoric binding is found in Ng.8. The reference used is $i$, for example:

(12)So, a living Komodo dragon seldom becomes supper for...
(13)And it does not have to compete very much for its own supper.

Sentence (13) in article Ad.8 portrays the use of reference it to point back to preceding sentence (20). Hence, the anaphoric binding is found.

The examples of anaphoric binding within they are found in Ng.6. One of the examples is provided below:

(18)When the adult bats leave the cave at night to feed, they are...

(20)And they get rid of mosquitoes, too. The sentence (20) shows the place of reference. It is found after the sentences that contain presupposed nouns. The sentence is (18). The references in (20) functions for referring back to the subjects in previous sentence (18).

\subsection{The Motifs of Reference}

2.2.1 Gender, Singularity and Plurality Palmer (1916: 124) stated animal can be classified as male (he) or female (she) if the gender is known. He also assumes that he or she is applicable to refer to human. This theory can complete Halliday and Hasan's assumption about reference to the animal. It is treated as human by using he or she, or as thing by using it (Halliday, Hasan, 1976: 47). In essence, it is supported by Palmer's assumption that the known gender of animal influences the use of he and she in text.

According to the result, the frequencies of she are 119 (40.8\%). Article $\mathrm{Ng} .5$ contains the dominant frequency of she. Article Ng.5 is in form of interviewing the trainer of archeological dog. It explains about the dog that is named Migaloo. The dog can smell bone that was buried in the past, the excerpt:

Australian dog trainer Gary Jackson of Multinational K9 has

trained a black lab mix named

Migaloo as the world's first

"archaeology dog," able to locate 
bones that are hundreds of years

old.

Migaloo is a female dog, it is seen in the reference she which is used to refer to the dog, for example in sentences (15), (16), (17), (18), (19):

(14)Why did you think Migaloo would be good at this kind of work? (15)She was a rescue dog from out in western Queensland, a black Labrador with a small cross of mastiff. (16) $\underline{\mathrm{Her}}$ name means "white fellow" in Aboriginal-it's an oxymoron. (17) She loves to play, and she's an absolute nut about her ball. (18) I think she would chase it till she drops dead. (19) So, once we trained her to recognize the odor of human bones, and taught her that she only gets her ball when she finds the target odor, she became...

The excerpt shows the interview about Migaloo. The 13 frequencies of she and her to talk about Migaloo indicates Migaloo as female dogs.

The dominant frequency of he is happened in Ad.2 because the topic is racehorses. There are ten profiles of racehorses that explain in Ad.2. All of the racehorses are used the reference he. An example is taken from John Henry as one of the famous racehorses:

(7) The 1980s were all about John Henry, voted the racehorse of the decade and also becoming the first to surpass $\$ 4$ million in career earnings in 1983. (8) $\underline{\mathrm{He}}$ was named after the "steel-driver" folk hero as a result of the equine's tendency as a youngster to tear down steel water and feed buckets off of stall walls and stomp them flat. (9)In addition to his 39 wins, he became the only horse to nab first place twice for both the Arlington Million and Santa Anita Handicap After.(10) his last race at the 1984
Ballatine Scotch Classic, he retired in 1985 as the world's richest thoroughbred.

The references he and his that used for referring to John Henry indicates that the racehorse is male.

Gender, singularity and plurality can influence the use of reference in text. $\mathrm{He}$ or she is influenced by known gender. It shows the unknown gender. And the reference they indicates the plural noun. It defines animals in general and in group.

\subsubsection{Association}

Halliday and Hasan's assumption about the reference for animal is related with association theory in semantic study. As one of imagery, association seems like metaphor (Johnson, 1970). It contains implications. The study of semantic is related with the assumption of animal reference. It influences the use of references that are treated as human or thing in text. Therefore it may show association as the factor.

The dominant frequencies of he is happened in Ad.2. The topic article is race horses. Horses are four big feet animal. It may imply to strength. There are ten profiles of racehorses that explain in Ad.2. All of the race horses are indicated by $h e$. Phar Lap is one of the race horses, for example:

(3)New Zealand-bred Phar Lap (which means "lightning" in Thai) became a national icon in Australia, where he primarily raced during his four-year career. (4)The monstrous horse measured a staggering 17.1 hands high while his heart weighed 13.7 pounds, significantly more compared to the average horse heart weight of just 9 pounds.

From the excerpt above the horse is used the reference he. Generally horse is considered as big animal that strong and great. Moreover, the using of word career in second line has tendency to treat horse 
as human. However it is possible that only male horses that may join the race.

NG.3 article represents the story of baby panda. It tells the activities of the baby panda. Similar with Ng.2 this article conveys that she used for baby animal. It is categorized as fragile animal, for example:

(16)Since the panda cams went dark the cub has grown and passed several developmental milestones. (17)She weighs five pounds (2.557 kilograms), up from 3.07 pounds (1.39 kilograms) at her veterinary exam September 26. (18) She also has partially opened her eyes.

The excerpt above tells the physic information of the baby. Nevertheless the birth in veterinary indicates that the gender is already known. In $\mathrm{Ng} .1$ the use of she intends to describe animal that nurturing other animals. Here animals has role as a mother even though the animals have ever been violated before. It is seen through the example:

(10)"When I first met Jasmine, you could tell she had been emotionally devastated but was a gentle dog by nature," Grewcock said.(11) "And soon, she started nurturing the other animals."

Based on the analysis above, there are two factors to use this reference. The reference she is written for fragile animals that needs help. It also represents a kind animal like a mother. So the association factor has weak evidences according to the data found. Therefore the analysis of association in this study is not conclusive.

\subsubsection{The Writer's Attitude}

The writer's attitude has important role in the use of reference that found in the data. So it is needed to analyze the attitude which may influence the use of reference. In Ad.6 article as seen in the example:

(9)So a naughty dog that goes on the carpet and gnaws up everything is probably not actively trying to punish its absent person for being gone so long. (10)But it might be feeling lonely and anxious, and not know how to behave when left on its own for so much time.

The writer used it to refer to the naughty dog. It shows that naughty as negative behavior influences the reference used. While in $\mathrm{Ng} .8$, the writer used he to point back to the dog, for example:

(16)This year's Best in Show is an English springer spaniel called Felicity's Diamond Jim.(17) His nickname is James.

From the example above it is seen that the dog has nice name. The name of the dog is name of dog show contestants. The dog in Ng.8 got special attentions. Therefore the writer used he instead of $i t$.

In $\mathrm{Ng} .10$ she is occurred to refer to a dog too. Ng.10 has nice animal topic. The example of she is seen in the following excerpt:

(39)As it turned out, Katie didn't need to steal. (41) She only had to beg.

The writer used she to refer to Katie (the dog's name) because of the good behavior of that dog. Here the writer's attitude is influenced the use of reference she.

The writer's attitude can influence the use of reference. It depends on favorable or unfavorable attitude. If the writers are favorable to the animal so they uses the reference he/she. And if they are not so it is used. However this motif is not enough for the generalization for this study because the data which contains animal behavior topics are less.

\section{Conclusion}

According to the result and discussion, there is a dominant reference she in the data. This dominant reference is found in anaphoric text. Its use is influenced by gender and singularity. In addition, the references he, it and they 
which also become the focus are influenced by gender, singularity, plurality and association.

Based on the analysis of class, function, and semantic category, reference is commonly used as head. In semantic category, the existential is dominant. The dominant occurrences of head and existential are caused by role of references in the sentences. The references have role as subject (he, she, it, they) and object (him, her, it, them) in the sentences. Related with anaphoric binding, the mediated (cohesive ties characteristic) is dominant because the presupposed noun is often repeated.

The use of each reference is influenced by different motifs. The reference she and he shows the gender and singularity of animal. $\mathrm{He}$ is used for male and she is used for female. Meanwhile the reference it refers to unknown gender and singularity of animal. They can influence the definiteness of presupposed noun. However some articles that contain specific presupposed noun help the reader to identify they which refer back to the presupposed noun. In addition, they can be definite in number but still indefinite in gender. Hence, gender, singularity also plurality have tendency to affect the use of reference in the data.

There are several associations found in the reference for animal. Race horse is strong and great. It is associated with male so the reference is he. Female animal nurtures its young. It is associated with mother. As the result, reference she is used.

Another association is that the female baby animal is very fragile. It is found in one of the article about violation. Nevertheless the evidences for this are not enough for generalization. Gender, singularity, and plurality commonly become the factors which influence the use of reference.
The writer's attitude may influence the use of reference. Favorable or unfavorable attitude are found in the data. If the writers are favorable to the animal so they uses the reference he/she. And if they are not so it is used. However this motif has weak evidences.

English does not convey gender for things. If the gender is unknown, so animal may be classified as thing. It needs another research to gather more evidences. Finally applying the theory of endophoric reference by Halliday Hasan and the semantic theory by Palmer in another research is needed to get better understanding on studying references for another object.

\section{References}

Bachmann, I. " Norm and variation on brazilian TV evening news programmes: The case of thirdperson direct-object anaphoric Reference1." Bulletin of Hispanic Studies, 88 (2011): n. 1-20. Web: http://search.proquest.com/docview /846931004? accountid=13771. 10 October 2013.

Bolinger, Dwight. "The Atomization of Meaning." Linguistic Society of America:Language, Vol. 41, No. 4 (1965) : n. 555-573. Web: http://www.jstor.org/stable/411524. 13 Desember 2013.

Fromkin, Victoria, Robert Rodman, Nina Hyams. An Introduction to Language seventh edition. Boston: Wodsworth, 2003.

Georgakopoulou, Alexandra and Dionysis Goutsos. Discourse Analysis: An

Introduction. Edinburg: Edinburg University Press, 1997

Gutwinski, Waldemar. Cohesion in Literary Text. Mouton: The Hague, 1976. Halliday, M A K and Ruqaiya Hasan. Cohesion in English. New York:

Longman, 
1976.

Halliday, $\mathrm{M}$ A $\mathrm{K}$. Introduction to

Functional Grammar. New York: Edward

Arnold Press, 1991.

Halliday, M A K and Ruqaiya Hasan.

Language, Text and Context. New York:

Longman, 1991.

Johnson, M. G. " A cognitive-features

model of compound free

associations".Psychol.Rev.(1970):

n. 77 pag. 282-293. Web. 23

December 2013.

Lyons, John. Semantic Volume I. London:

Cambridge University Press, 1977.

Lyons, John. Semantic Volume II.

London: Cambridge University

Press, 1977.

Palmer, F.R. Semantics Second Edition. New York: Cambridge University Press,

1916.

Serratice, L. "Cross-linguistic influence in the interpretation of anaphoric and cataphoric pronouns in englishitalian bilingual children". Bilingualism, 10(3) (2007): n. 225-238. Web: http://search.proquest.com/docview $/ 199783685$ ?accountid $=13771.10$ October 2013. 